\title{
A Teoria da Dupla Herança e a Evolução da Moralidade
}

\author{
FÁbio Portela Lopes de Almeida \\ Universidade de Brasília \\ Paulo Cesar Coelho Abrantes \\ Universidade de Brasília
}

\begin{abstract}
A darwinian evolutionary approach can contribute to reassess philosophical problems in different fields, including ethics and moral theory. Sociobiology and evolutionary psychology address these issues by presupposing mechanisms such as kin selection and reciprocal altruism. However, these mechanisms can't account for cooperation in the human species. Dual inheritance theory addresses human cooperation differently, by taking into account the above-mentioned classical biological mechanisms without ignoring, however, relevant knowledge produced by social scientists. According to this approach, human social psychology comprises tribal social instincts and symbolic markers. One implication of this approach is that there are innate and universal moral principles hardwired in the human mind-brain, which where selected through an evolutionary process that makes life possible in large, structured social groups. Although innate, these principles are plastically shaped to meet the demands of different cultural niches in particular societies.
\end{abstract}

Keywords: Dual inheritance; evolution of morality; ethics; darwinism.

\section{Introdução}

O direito, a religião e a moral, instituições típicas de qualquer sociedade humana, regulam a conduta humana porque somos capazes de agir de acordo com normas. Religiões prescrevem a obediência a certos preceitos, assim como o direito e a moral demandam que os indivíduos se comportem de acordo com normas jurídicas e morais. Mas qual a origem da capacidade de raciocinar normativamente?

Quando procuramos exemplos de comportamentos similares na natureza, não encontramos outra espécie que os apresente com a sofisticação do Homo Sapiens. Por essa razão, a normatividade da vida social humana é um desafio para a biologia evolutiva, que assume como pressuposto a gradualidade do processo evolutivo: a evolução não se dá em saltos, mas em passos pequenos e cumulativos. Como nenhuma outra espécie apresenta a capacidade de formulação de juízos morais como a nossa, a normatividade presente nas sociedades humanas parece ser um mistério que desafia a teoria darwinista.

O propósito do presente artigo é o de mostrar como esse desafio tem sido enfrentado por biólogos, filósofos e antropólogos que pressupõem o quadro teórico

Principia 16(1): 1-32 (2012).

Published by NEL — Epistemology and Logic Research Group, Federal University of Santa Catarina (UFSC), Brazil. 
darwinista. Na primeira seção, objetiva-se explicitar a proposta da sociobiologia, uma das várias teorias biológicas que buscaram explicar o comportamento social humano nessas bases. Assim, serão exploradas tanto as virtudes dessa proposta quanto os seus limites - em especial, a importância secundária que a sociobiologia concede à cultura na explicação da sociabilidade humana.

Na segunda parte do artigo, pretende-se elucidar os pressupostos das teorias da coevolução gene-cultura (e, em especial, da teoria da dupla herança), um conjunto de abordagens teóricas recentes que enfrentou o problema a partir de uma premissa diversa: a de que a cultura teve um papel preponderante na evolução da psicologia moral humana. Além disso, pretende-se explorar como essa perspectiva, delineada por Peter Richerson e Robert Boyd, pode contribuir para explicar a evolução de uma mente normativa.

\section{A sociobiologia e a explicação da moralidade humana}

Até a década de 1960, não havia sido proposto um mecanismo biológico a partir do qual fosse possível explicar adequadamente a cooperação na natureza. ${ }^{1} \mathrm{O}$ mecanismo proposto até então, a seleção de grupo, era considerado insatisfatório, porque assumia um pressuposto que, a rigor, dificilmente poderia ser explicado no âmbito do paradigma darwinista: a de que os animais cooperam entre si para o bem de seu grupo social ou o de sua espécie, como defendido, por exemplo, por Wynne-Edwards.

A seleção de grupo, contudo, passou a ser muito criticada na década de 1960 . Uma primeira crítica, de conteúdo metodológico, partiu do trabalho de George C. Williams, que propôs a adoção de um princípio de parcimônia: os cientistas não deveriam invocar adaptações no nível do grupo, a menos que fosse estritamente necessário. George C. Williams, Hamilton, Trivers, Smith e a teoria dos jogos mostrariam, mais tarde, que o comportamento altruísta poderia ser explicado por outros mecanismos. Uma outra crítica de Williams era a de que Wynne-Edwards confundia adaptações de grupo com benefícios fortuitos para o grupo. Adaptações de grupo seriam características que realmente evoluíram por seleção de grupo, ao passo que benefícios fortuitos teriam outras causas. Por exemplo, uma característica benéfica para o indivíduo também poderia, eventualmente, beneficiar o grupo embora evolua por meio de uma ortodoxa seleção no nível do indivíduo (Okasha 2006, p. 2306-11).

Mas a biologia evolutiva passou por uma reestruturação nas décadas de 1960 e 1970, a partir das pesquisas de Hamilton, que desencadearam o surgimento da sociobiologia (Ruse 1983, p. 13), disciplina que objetivava ser uma síntese de todo o conhecimento biológico e que se propunha a explicar a comunicação, o modo pelo qual as diferentes espécies se agrupam, o cuidado parental, a punição e o altruísmo em todas as espécies animais (Laland \& Brown 2002, p. 72). O propósito desta 
seção é expor os principais elementos das explicações sociobiológicas, bem como suas deficiências para responder pela cooperação no caso humano.

\subsection{Genes egoístas podem explicar o comportamento altruísta?}

A sociobiologia busca explicar características comportamentais propondo uma resposta para a seguinte questão: a quem a seleção natural favorece? Ao contrário dos proponentes da seleção de grupo, aquela abordagem supõe que muitos comportamentos altruístas dos animais poderiam ser explicados por princípios mais simples, desde que o investigador leve em conta um nível mais baixo de seleção: o dos genes. Um gene não é selecionado porque é bom para o indivíduo ou para o grupo, mas porque produz indivíduos capazes de maximizar a representação do próprio gene nas gerações futuras (Laland \& Brown 2002, p. 74). Assim, a pergunta da sociobiologia "a quem a seleção natural favorece?" traz o gene como resposta. O teórico deve adotar a perspectiva do gene (ou o ponto de vista do gene) para explicar o comportamento animal (entre outras características), buscando sempre a resposta para a seguinte questão: como os genes do animal se beneficiam com o modo como se comporta? A tese de que é possível explicar o comportamento a partir da perspectiva do gene foi bastante popularizada por Richard Dawkins, que a imortalizou na expressão 'o gene egoísta' (Dawkins 2001, p. 40; Laland \& Brown 2002, p. 75).

A cooperação dificilmente poderia evoluir na situação em que indivíduos são capazes de aproveitar as oportunidades de agir em benefício próprio em detrimento dos demais indivíduos, já esses 'aproveitadores' (free-riders) deixariam mais herdeiros na próxima geração do que os indivíduos altruístas. ${ }^{2}$ Outro aspecto que dificultaria a ocorrência do mecanismo da seleção de grupo é a migração de indivíduos entre grupos. Caso a migração ocorra, as diferenças genéticas entre os membros de diferentes grupos se tornam cada vez menores, diminuindo consequentemente a intensidade da seleção no nível do grupo, já que a variação (entre grupos, no caso) é condição para que a seleção natural possa atuar.

Mas a perspectiva de que a seleção natural atua fundamentalmente no nível genético poderia trazer uma explicação mais parcimoniosa do que a proposta pela seleção de grupo, uma vez que não depende do recurso injustificado à seleção natural em níveis superiores, o que poderia contornar os problemas indicados. Desse modo surgiram contribuições valiosas - em especial, os conceitos de seleção de parentesco e de altruísmo recíproco, que serão apresentados a seguir.

\subsection{A seleção de parentesco}

A seleção de parentesco (kin selection) foi um mecanismo proposto por William Hamilton que revolucionou a compreensão do comportamento animal. Segundo ele, 
a chave para compreender como um comportamento altruísta poderia evoluir por seleção natural é o grau de proximidade genética entre os indivíduos envolvidos. A ideia básica é a de considerar os custos e benefícios da ação altruísta: um indivíduo que ajuda outro incorre em um custo (c) para si mesmo, que pode ser expresso na diminuição da probabilidade de deixar herdeiros, mas o ato causa um benefício (b) para o receptor da ação altruísta (Laland \& Brown 2002, p. 76; Dawkins 2001, p. 118; Sober \& Wilson 1998, pp. 58-61). Mas Hamilton propôs a inclusão de uma terceira variável $r$ (de relatedness, ou parentesco), como medida da probabilidade de que os indivíduos compartilhem os mesmos genes. Se o parentesco entre o doador e o receptor da ação altruísta for muito próximo, faz sentido, evolutivamente, que um ajude o outro, porque o resultado do ato eleva a probabilidade de que os genes do doador, que são compartilhados com o receptor, se propaguem. Segundo Hamilton, a seleção do comportamento altruísta ocorre sempre que o custo de ser altruísta for inferior à multiplicação do benefício para o receptor pelo grau de parentesco, seguindo a equação $c<b r$.

Assim, a evolução do altruísmo é provável sempre que o ato altruísta aumente as chances de que os receptores da ação propaguem os genes compartilhados com o doador. Hamilton cunhou o termo 'aptidão inclusiva' (inclusive fitness) para explicar essa ideia: a aptidão do indivíduo depende não apenas de sua descendência direta (aptidão clássica), mas também da aptidão resultante do ato altruísta, que aumenta a probabilidade de que os receptores de seu ato propaguem os genes compartilhados. ${ }^{3}$

A seleção de parentesco é capaz de explicar vários comportamentos tidos por altruístas como, por exemplo, o dos insetos sociais da ordem Hymenoptera (que compreende vespas, formigas e abelhas), que compartilham entre si um percentual muito elevado de genes, satisfazendo as condições para a atuação do altruísmo recíproco.

A seleção de parentesco é uma causa última do comportamento altruísta não apenas nos insetos sociais, mas em boa parte dos demais animais. ${ }^{4}$ É bastante comum na natureza, por exemplo, o cuidado parental - alguns animais cuidam de seus filhos até que eles se tornem capazes de sobreviver autonomamente. Além disso, o cuidado com irmãos e outros parentes próximos também é uma constante na natureza, revelando-se resultado evolutivo da seleção de parentesco. A rigor, a seleção de parentesco explica muito do próprio processo evolutivo nas chamadas 'transições em individualidade': podemos conceber as células de um indivíduo multicelular, por exemplo, como irmãs gêmeas que partilham o mesmo destino genético (Szathmáry \& Wolpert 2002, p. 283).

\subsection{O altruísmo recíproco}

Outro mecanismo apresentado pelos biólogos para a evolução da cooperação é o chamado altruísmo recíproco, que foi delineado por Robert Trivers em 1971 e, mais 
adiante, formalizado matematicamente pela teoria dos jogos. Trivers sugeriu que, se indivíduos não aparentados interagissem por um grande e indefinido período de tempo, o comportamento altruísta poderia ser selecionado se houvesse alta probabilidade de o receptor o devolver, no futuro, ao doador inicial (Trivers 1971).

Um dos principais problemas para a teoria do altruísmo recíproco, contudo, é a possibilidade, sempre presente, de que indivíduos aproveitadores se infiltrem em uma comunidade de indivíduos altruístas. Se isso acontecer, os aproveitadores têm uma nítida vantagem em termos de aptidão biológica, pois são os receptores dos atos altruístas, mas não têm custo algum associado aos atos altruístas. Como resolver esse problema? Indivíduos com uma psicologia razoavelmente complexa, capaz de diferenciar os aproveitadores dos altruístas, poderiam se isolar em comunidades fechadas, dirigindo os atos altruístas apenas para outros indivíduos altruístas e excluindo os aproveitadores (Dennett 2003, pp. 199-200). Além disso, essa psicologia também poderia sustentar a prática da punição moral, isto é, de punir os aproveitadores, distribuindo os custos da punição entre todos os membros de uma comunidade.

Embora o altruísmo recíproco já tenha sido sugerido como um mecanismo capaz de explicar a cooperação em várias espécies animais, as evidências são inconclusivas pois, muitas vezes, o comportamento poderia ser explicado por outros mecanismos, como a seleção de parentesco ou o mutualismo, em que os indivíduos recebem benefícios imediatos, e não em interações futuras (Laland \& Brown 2002, pp. 83-4; Richerson \& Boyd 2005, p. 199). Apesar disso, o primatólogo Frans de Waal sugere que o altruísmo recíproco exerceu um papel importante na evolução dos primatas em especial, no caso dos chimpanzés, que teriam uma psicologia preparada para raciocinar com base na reciprocidade (De Waal 2009, pp. 172-3). Ele também sustenta que a capacidade para identificar relações potencialmente recíprocas, elemento essencial para o funcionamento do altruísmo recíproco, fundamenta um certo senso normativo (de justiça) entre primatas, orientado a partir da aversão à desigualdade (De Waal 2009, p. 187; De Waal 2006).

\subsection{Limitações dos mecanismos propostos pela sociobiologia para explicar a cooperação humana}

A sociobiologia, como visto, explica a cooperação a partir de dois mecanismos básicos: a seleção de parentesco e o altruísmo recíproco. A partir de experimentos realizados com animais, os sociobiólogos começaram a refletir sobre a possibilidade de que esses mecanismos tenham tido um papel na própria história evolutiva humana. Edward O. Wilson, o responsável pela popularização do 'sociobiologia', resumiu o projeto nos seguintes termos:

Os seres humanos herdaram uma propensão para adquirir comportamen-

Principia 16(1): 1-32 (2012). 
tos e estruturas sociais, compartilhada por um número suficiente de pessoas para que possa ser chamada de natureza humana. Os traços definidores incluem a divisão do trabalho entre os sexos, os laços entre parentes, o repúdio ao incesto, outras formas de comportamento ético, a suspeita com relação a estrangeiros, tribalismo, ordens de dominação dentro de grupos, a dominância do macho sobre todos e a agressão territorial em razão dos recursos limitados. Embora as pessoas tenham livre arbítrio e possam se voltar para muitas direções, os canais de seu desenvolvimento psicológico são contudo — embora queiramos desejar muito o contrário - definidas muito mais profundamente pelos genes em certas direções do que em outras. Enquanto as culturas variam enormemente, elas inevitavelmente convergem para esses traços (Wilson 1994, pp. 332-3).

E, de fato, os mecanismos descobertos pelos sociobiólogos sugerem hipóteses promissoras para explicar a cooperação humana. Segundo Robert Wright, por exemplo, grande parte da própria psicologia humana foi moldada pela seleção de parentesco (Wright 1994, p. 161). Não há cultura em que os pais não cuidem de seus filhos (mesmo que sob certas circunstâncias exijam o seu sacrifício), e alguns experimentos sociais já demonstraram que o altruísmo é mais dirigido a parentes próximos do que a parentes distantes ou a desconhecidos (Henrich \& Henrich 2007, p. 96).

No entanto, apesar de ser uma causa importante do comportamento altruísta, a seleção de parentesco é insuficiente para explicar tudo o que se refere à cooperação humana. Afinal, os humanos não cooperam apenas com parentes próximos. E essa não é uma particularidade humana, uma vez que já foi registrada a prática de atos altruístas de animais não-humanos voltados para membros de espécies diferentes. Assim, mesmo que a maioria dos comportamentos altruístas, em outras espécies, seja dirigida a parentes próximos, é preciso reconhecer a limitação da seleção de parentesco para explicar todo o horizonte de possíveis comportamentos ligados à cooperação (De Waal 2009, p. 180).

O altruísmo recíproco também parece ter sido um mecanismo importante no passado evolutivo humano. Trivers afirmou que o altruísmo recíproco provavelmente evoluiu nos pequenos grupos sociais em que os ancestrais humanos viveram nos últimos milhões de anos, pois as condições de vida nesses grupos eram ideais para a evolução desse mecanismo. Nas palavras de Laland e Brown:

O sistema que evoluiu deveria possibilitar que os humanos usufruíssem dos benefícios das trocas altruístas e se protegessem de formas grosseiras e sutis de oportunismo, mas praticassem formas de oportunismo quando fosse lucrativo. Além disso, ele [Trivers] sugeriu que a evolução do altruísmo recíproco providencia uma explicação para certas características comportamentais humanas. Por exemplo, a necessidade da amizade é adaptativa porque nos motiva a encontrar indivíduos com os quais podemos trocar atos altruístas e nos associar a eles. A punição moral, por outro lado, evoluiu de modo

Principia 16(1): 1-32 (2012). 
que os oportunistas não se saíssem impunes, enquanto a gratidão por parte do receptor da gentileza é adaptativa porque faz com que o doador acredite que o beneficiado provavelmente retribuirá em uma ocasião futura (Laland \& Brown 2002, p. 84).

É inegável que o altruísmo recíproco traz novas possibilidades de explicação de certos comportamentos quando comparado com a seleção de parentesco, que é incapaz de explicar como indivíduos podem agir na defesa de outros indivíduos com os quais não são relacionados geneticamente. O altruísmo recíproco, por sua vez, expande o universo de receptores da ação altruísta pois, potencialmente, inclui qualquer um que possa interagir com um indivíduo. Apesar disso, esse mecanismo também padece de problemas teóricos que o tornam incapaz de explicar todo o horizonte da ação moral humana.

$\mathrm{O}$ primeiro problema diz respeito à metodologia utilizada pelos modelos matemáticos para formular o problema da cooperação. Ao invés de efetuarem as simulações em grupos grandes, compostos por centenas de agentes, os primeiros modelos utilizaram estruturas sociais simples, compostas por apenas dois agentes (díades).

Um dos problemas de utilizar modelos diádicos para simular sociedades mais complexas pode ser percebido no estudo dos efeitos do problema do oportunismo para a evolução da cooperação (Henrich \& Henrich 2007, p. 42). A evolução de um sistema de cooperação incapaz de isolar os oportunistas seria improvável porque eles sempre seriam capazes de obter os benefícios da cooperação sem contribuir para ela. Com menos custos, a probabilidade de deixar mais herdeiros do que os agentes cooperadores é maior, o que levaria, no longo prazo, à extinção dos cooperadores e à proliferação dos oportunistas.

Alguns problemas relacionados ao oportunismo dizem respeito à cooperação em grupos maiores compostos por indivíduos não aparentados - que é, justamente, a peculiaridade dos grupos humanos. O primeiro desses problemas é o da escalada de deserção que ocorre em grupos grandes. Um único indivíduo oportunista pode induzir todos os outros a pararem de cooperar (desertar - to defect - é o termo utilizado em teoria dos jogos para descrever esse comportamento). Mas a deserção generalizada gera ainda mais deserções, porque os outros agentes também deixam de cooperar em reação aos primeiros agentes que deixaram de fazê-lo. O efeito deletério dessa reação em cadeia seria a inviabilização da cooperação a longo prazo. Por outro lado, se os altruístas tolerassem os oportunistas, estes se beneficiam no longo prazo - o que levaria à evolução de um grupo totalmente composto por oportunistas. Por essa razão, o altruísmo recíproco, por si só, é capaz de sustentar a cooperação apenas em pequenos grupos, como as díades, em que a punição neutraliza os oportunistas sem induzir a uma escalada de punições (Richerson \& Boyd 2005, pp. 199-200; Henrich 2007, p. 51; Richerson et al. 2002, p. 360). 
Além disso, o altruísmo recíproco padece de um outro problema que o impede de sustentar a cooperação em grupos maiores. Quanto maior é o grupo, menor o efeito sofrido pelo agente oportunista pelo fato de um indivíduo altruísta não cooperar mais com ele (em retaliação). Isso significa dizer que os custos de ser oportunista (a probabilidade de sofrer retaliação) são proporcionalmente menores quanto maior a população. Esse fenômeno é conhecido como diminuição marginal do custo da retaliação. Em um grupo muito grande, o efeito da punição aplicada isoladamente por um indivíduo é muito pequeno, pois ainda haverá uma grande parcela da população a ser explorada por um oportunista. Nesses grupos, vale a pena ser oportunista porque é menor o efeito da reação individualizada dos agentes explorados (Richerson \& Boyd 2005, p. 200).

Por essas razões, os mecanismos delineados pela sociobiologia não são suficientes para explicar a evolução de uma mente normativa, que habilita a nós, humanos, vivermos em um mundo composto por instituições que operam com base em normas morais e jurídicas. Isso não significa, contudo, que a tentativa de utilizar a biologia como ponto de partida para explicar o comportamento normativo humano esteja fadada ao fracasso. Recentemente, muitas linhas de pesquisa alternativas à sociobiologia procuraram explicar como nossa moralidade evoluiu. O restante do artigo se dedicará a explorar como uma dessas linhas de pesquisa - a chamada teoria da dupla herança - explica a evolução da mente normativa. Segundo essa abordagem, o altruísmo humano e nossa capacidade de raciocinar a partir de normas somente podem ser adequadamente explicados se os biólogos voltarem seus olhares para a função evolutiva de uma característica que os cientistas sociais sempre consideraram ímpar no caso humano: a cultura.

\section{A evolução da mente normativa: as contribuições da teoria da dupla herança}

As teorias da coevolução gene-cultura buscam explicar o comportamento humano a partir da premissa de que a cultura é sua causa. De acordo com a tese delineada por Richerson e Boyd, que ficou mais conhecida como teoria da dupla herança, a cultura é responsável não apenas por guiar o comportamento de indivíduos em harmonia com as normas de um determinado grupo (cultura compreendida como causa próxima do comportamento), mas também é um fator fundamental para compreender a própria evolução da espécie humana. Nossos ancestrais foram seres culturais, e partir desse pressuposto é fundamental para se explicar como a psicologia humana evoluiu. O fundamento central das teorias da coevolução gene-cultura é o de que a mente humana é fruto de um processo evolutivo em que tanto forças genéticas quanto forças nitidamente culturais estiveram presentes e se influenciaram mutuamente.

Principia 16(1): 1-32 (2012). 
Essa perspectiva a torna fundamentalmente distinta das abordagens propostas pela sociobiologia e pela psicologia evolucionista. Nestas últimas, a cultura é apenas o fruto de uma psicologia que evoluiu, na linhagem hominínea, com base exclusiva em uma herança genética clássica. Segundo uma boutade dos sociobiólogos, que se tornou bastante popular, os genes mantêm a cultura sob rédea curta. A teoria da dupla herança retruca, por sua vez, que "A cultura está sob uma rédea, é verdade, mas o cachorro no fim da coleira é grande, esperto e independente. Em uma caminhada, é difícil dizer quem está levando quem" (Richerson \& Boyd 2005, p. 195).

A teoria da dupla herança se baseia, de modo fundamental, no que Ernst Mayr chamou de 'pensamento populacional'. Antes de Darwin, as espécies eram consideradas essências imutáveis, mas o cientista inglês percebeu que as espécies eram populações de indivíduos com diferenças em suas características e que parte dessa variação era herdada ao longo do tempo (Richerson \& Boyd 2005, p. 5). Nessa perspectiva, a seleção natural é entendida como um processo que afeta a proporção dessas características na medida em que os indivíduos que as possuem são mais aptos, ou seja, deixam mais descendentes. Ao longo do tempo, o pool de variantes (que hoje sabemos ter uma base genética), altera-se gradativamente, podendo-se dizer que a espécie, nessa medida, "evolui".

No contexto de um pensamento populacional, convém explicitar o conceito de cultura pressuposto por Richerson e Boyd:

A cultura é informação capaz de afetar o comportamento dos indivíduos e que eles adquirem de outros membros de sua espécie a partir do ensino, da imitação, e de outras formas de transmissão social (Richerson \& Boyd 2005, p. 5).

Em primeiro lugar, ressaltamos que se trata de uma abordagem informacional a respeito da cultura. A informação é definida como o conteúdo de "qualquer tipo de estado mental, consciente ou não, que é adquirido ou modificado pelo aprendizado social e afeta o comportamento" (Richerson \& Boyd 2005, p. 5). A cultura é informação armazenada nos cérebros de indivíduos, adquirida por meio de mecanismos de aprendizado social (imitação, ensino) e individual (observação).

Essa definição de cultura é, em segundo lugar, adequada a um tratamento populacional: como a cultura é essencialmente informação particularizada na forma de variantes culturais, é possível rastrear a mudança na proporção de cada variante no conjunto (pool) de variantes culturais existentes em uma dada população em certo instante de tempo. Assim como os genes, as variantes culturais variam na população em função de uma série de fatores: determinadas variantes são mais fáceis de ser memorizadas e ensinadas; outras levam os indivíduos a ter mais sucesso em suas vidas e, por isso, são mais imitados. Pelas mais diversas razões, algumas variantes culturais são mais imitadas do que outras e tendem a persistir, ao passo que outras 
variantes tendem a desaparecer. Torna-se possível, desse modo, explicar os padrões de variação cultural (Richerson \& Boyd 2005, p. 6) ${ }^{5}$

O pensamento populacional também informa o modo pelo qual a teoria da dupla herança se relaciona com a teoria social. Richerson e Boyd, embora reconheçam a necessidade de o modelo da teoria dupla herança incorporar o conhecimento das ciências sociais, ambos rejeitam a ideia de que a cultura é um processo supraindividual que independe dos agentes que transmitem, recebem e manipulam as variantes culturais: a dinâmica cultural pressupõe processos que ocorrem, fundamentalmente, no plano psicológico.

Pensar a cultura a partir de processos que ocorrem em indivíduos - enquanto informação que é adquirida, transmitida e armazenada em mentes individuais possibilita explorar as relações entre os fenômenos culturais e os fundamentos biológicos da psicologia humana. O estudo da psicologia humana, segundo uma perspectiva evolutiva, deve explicitar os mecanismos pelos quais nossas mentes lidam e estruturam a cultura, possibilitando, por exemplo, que se identifique quais crenças e ideias são particularmente mais fáceis (ou mais difíceis) de ser manipuladas, aprendidas e ensinadas (Richerson \& Boyd 2005, p. 8).

A dinâmica evolutiva da própria cultura também é fundamental para compreender a evolução humana. O pensamento populacional incita a que a reflexão se dê nos dois níveis - do indivíduo, considerando-se a evolução das capacidades psicológicas envolvidas na aquisição/transmissão da cultura; e no nível da própria população de variantes culturais, compreendendo tanto como a distribuição dessas variantes é influenciada por aquela psicologia, quanto como a própria cultura, em um tempo evolutivo, também moldou uma psicologia social específica.

A cultura é compreendida por esta abordagem como um sistema de herança: as variantes culturais presentes em um pool cultural modificam-se ao longo do tempo, de forma que as variantes presentes no início do processo se tornam bastante diferentes daquelas que se apresentam posteriormente. Por essa razão, é importante distinguir a mera posse de uma cultura, da acumulação cultural, em que as novas variantes culturais criadas por uma geração sejam agregadas à cultura herdada e transmitida, por sua vez, às gerações seguintes. Este é o traço distintivo da cultura humana, que a diferencia da cultura observada em outros animais. Uma vez que nossos ancestrais se tornaram capazes de aprender, transmitir e acumular variantes culturais, inaugurou-se um novo sistema de herança, análogo ao genético e sujeito à ação de forças evolutivas específicas. ${ }^{6}$ A compreensão da dinâmica cultural em termos evolutivos é essencial para entender como a teoria da dupla herança lida com o problema de como a cooperação observada em grupos humanos pode ter evoluído.

Principia 16(1): 1-32 (2012). 


\subsection{A evolução cultural}

O Homo sapiens somente pôde ocupar grande parte dos ambientes terrestres por ser dotado da capacidade de aprender com rapidez, por meio da herança cultural, os comportamentos adequados para sobreviver em circunstâncias ambientais com um certo grau de variabilidade. A capacidade psicológica requerida para que haja acumulação cultural é uma adaptação biológica. Mas o seu surgimento implicou uma revolução na história natural paralela ao aparecimento de moléculas capazes de se auto-replicar, como o RNA ou o DNA (Dawkins 2001, pp. 213-4). Trata-se de um novo sistema de herança, ao lado do genético, com dinâmica e características próprias.

A abordagem darwinista de Richerson e Boyd busca explicar porque certas variantes culturais se disseminam, ao passo que outras diminuem sua participação no conjunto de variantes de uma população - analogamente a como se explicam as mudanças de frequência dos alelos genéticos (Richerson \& Boyd 2005, p. 60). Assim como ocorre na evolução com base em herança genética, o surgimento de variantes culturais complexas é explicado como o resultado de um longo processo de acumulação de pequenas e graduais variações, que envolvem várias gerações de indivíduos. Uma das vantagens dessa abordagem, ao tratar a evolução cultural analogamente à evolução genética, é a de explicar a alteração da frequência das variantes culturais a partir do mesmo princípio. Em ambos os sistemas de herança, a mudança de frequência das variantes consideradas se deve à atuação de determinadas forças. ${ }^{7}$

$\mathrm{Na}$ evolução genética, fatores como a seleção, mutação e deriva alteram a distribuição dos alelos de uma população. Do mesmo modo, os autores propõem que a alteração da frequência das variantes culturais se deve a determinadas forças. Algumas delas, como a seleção, a mutação e a deriva, são análogas à evolução genética; outras, contudo, são forças especificamente culturais. Richerson e Boyd propõem a classificação das forças evolutivas que atuam sobre as variantes culturais em três grupos: a) forças aleatórias (random forces); b) forças de tomada de decisão (decisionmaking forces); e c) seleção natural.

As forças aleatórias são análogas às da evolução genética: a mutação (uma variante cultural é aprendida equivocadamente e transmitida para outro indivíduo) e a deriva (anomalias estatísticas em populações pequenas tornam mais provável o desaparecimento de determinadas variantes culturais). As forças de tomada de decisão, por sua vez, se dividem em duas modalidades: a variação guiada, que é a modificação intencional da informação cultural adquirida pelo indivíduo e que é subsequentemente transmitida; e a transmissão enviesada, que ocorre quando as pessoas adotam preferencialmente algumas variantes culturais em detrimento de outras.(Richerson \& Boyd 2005, p. 69). Isso indica que a psicologia humana é afetada por viéses (biases) que afetam o modo pelo qual a mente humana assimila as 
variantes culturais. Esses viéses podem ser inatos ou adquiridos culturalmente.

A transmissão cultural é afetada por três viéses distintos: o viés de conteúdo (um indivíduo assimila uma variante cultural em decorrência de seu conteúdo); o viés dependente da frequência (que favorece o aprendizado da variante cultural com base na frequência com que ela está presente na população em um determinado momento); e o viés de seguir modelos (a imitação preferencial das variantes culturais associadas aos indivíduos de sucesso ou de prestígio na população). De especial importância para a teoria da cooperação é um viés específico dependente da frequência: o viés conformista, que favorece o aprendizado das variantes culturais mais disseminadas em uma população. Segundo Richerson e Boyd, o viés conformista é uma das forças mais importantes da evolução cultural, e tem um forte papel na evolução humana (Richerson \& Boyd 2005, p. 69).

A seleção natural é o terceiro tipo de força que atua na evolução cultural, e segue a mesma lógica da seleção natural convencional. A seleção natural atuando sobre variantes culturais pode ser definida como a modificação da composição cultural de uma população, decorrente dos efeitos das variantes culturais para quem as adota (Richerson \& Boyd 2005, p. 69). Contudo, há uma importante distinção a ser feita entre a seleção natural atuando sobre a dinâmica genética e seu análogo atuando sobre a dinâmica cultural. No primeiro caso, são selecionados indivíduos biologicamente mais aptos. Isso não é necessariamente verdadeiro no caso da seleção natural aplicada às variantes culturais - embora algumas variantes sejam selecionadas por tornar um indivíduo biologicamente mais apto, a evolução cultural também pode estar vinculada à disseminação de variantes culturais pelo fato de o indivíduo que as adota tornar-se, por essa razão, mais atraente como modelo a ser imitado por outros indivíduos (Abrantes \& Almeida 2011, p. 273).

As características específicas da evolução cultural a tornam um processo diferente da evolução genética e relativamente autônomo com respeito a esta última e denotam as diferenças entre a teoria da dupla herança e a sociobiologia. Para os sociobiólogos, a seleção natural atua primordialmente sobre os genes que codificam a psicologia individual, moldando dessa forma os viéses envolvidos na aquisição e na transmissão da cultura. Nessa perspectiva, a seleção natural teria moldado a psicologia humana de maneira a favorecer a aquisição de variantes culturais adaptativas, que aumentassem a aptidão biológica. Todavia, esse não é sempre o caso: modelos matemáticos propostos por Richerson e Boyd sugerem que a evolução cultural pode favorecer a aquisição de variantes culturais mal-adaptativas (do ponto de vista biológico), em razão dos processos de transmissão cultural. Na evolução biológica tradicional, a informação genética é transmitida apenas verticalmente, dos pais para os filhos, o que favorece a transmissão de genes que elevam a aptidão biológica, uma vez que os indivíduos menos aptos deixam menos descendentes do que os mais aptos, o que garante a propagação de genes codificadores de comporta- 
mentos adaptativos. Na evolução cultural, contudo, isso pode não acontecer, porque os indivíduos aprendem variantes culturais de virtualmente qualquer outra pessoa (Boyd et al. 2005, p. 401). Essa característica abre a possibilidade de que a evolução cultural seja mal-adaptativa. Por outro lado, a evolução cultural também pode ser adaptativa: alguém pode ser mais imitado justamente porque adota variantes culturais codificadoras de comportamentos adaptativos.

É importante salientar que embora seja possível a difusão de determinadas variantes culturais mal-adaptativas, ainda assim a cultura como uma modalidade de herança constitui uma adaptação biológica. Mesmo que determinadas variantes culturais sejam mal-adaptativas, a totalidade das variantes culturais de uma sociedade é responsável pela solução rápida de vários dos problemas ambientais, sociais e culturais enfrentados. A evolução cultural possibilitou o aprendizado rápido e flexível de novos comportamentos, mas ao custo de que alguns desses comportamentos não sejam adaptativos. Do ponto de vista individual, é sempre possível adquirir variantes culturais mal-adaptativas, que no longo prazo diminuirão a aptidão de quem as adota. Todavia, no nível do grupo, todo o conjunto de variantes culturais existentes - as crenças, valores, normas, instituições que caracterizam aquela população pode ser adaptativo, porque traz várias soluções para os problemas enfrentados pelo grupo.

\subsection{A teoria da dupla herança e o retorno da seleção de grupo}

Outro elemento importante no esquema explicativo da teoria da dupla herança é o papel da seleção de grupo. Da década de 1970 em diante boa parte dos biólogos rejeitou a seleção de grupo como uma força relevante na evolução. As circunstâncias em que a seleção de grupo poderia se compor à seleção natural atuando no nível do indivíduo/gene são tão específicas e raras que ela foi, por muito tempo, negligenciada. A teoria da dupla herança, contudo, atribui um papel central à seleção de grupo na evolução humana. Segundo essa perspectiva, a dinâmica da evolução cultural, por suas características particulares, possibilitou a satisfação inequívoca das condições necessárias para que a seleção de grupo pudesse ser um fator relevante ao lado da seleção individual. ${ }^{8}$

A evolução darwiniana depende da satisfação de três condições para que possa ocorrer: variação, herança e seleção. Em princípio, a seleção natural pode atuar em qualquer nível — genes, indivíduos ou grupos (Dennett 1998), ou mesmo em vários deles simultaneamente, resultando em uma particular trajetória evolutiva. Para que haja seleção no nível dos grupos é necessário que cada grupo seja diferente de outros grupos (variação); que ele possa transmitir suas características adaptativas para os grupos 'descendentes' (herança); e que haja limites para a coexistência dos diversos grupos, o que leva à competição e à seleção do grupo mais apto.

Principia 16(1): 1-32 (2012). 
Evidências importantes indicam que essas condições são satisfeitas no caso dos grupos humanos. O mecanismo de herança, nesse caso, é a própria cultura, que pode acumular-se dadas certas condições, como debatido na seção anterior. A variação, por sua vez, decorre das diferenças culturais existentes entre as diversas sociedades humanas. Para que a seleção natural atue no nível do grupo, a variação entre os grupos não precisa ocorrer necessariamente no nível genético. E o fato de o Homo sapiens estar sujeito a um segundo sistema de herança - a cultura - possibilitou que a variação ocorresse sobretudo nesse plano. As sociedades humanas são culturalmente diferentes entre si, ou seja, o pool de variantes culturais de cada sociedade é distinto. E é exatamente por possibilitar que grupos diferentes se adaptem a uma ampla faixa de ambientes que as capacidades para a acumulação cultural evoluíram em nossa espécie, como visto nas seções anteriores.

Por si só, contudo, a simples existência de variação entre os grupos não é uma condição suficiente para que a seleção de grupo se torne uma força evolutiva a ser contabilizada. É preciso que essa variação seja mantida ao longo do tempo. Segundo Richerson e Boyd, há dois mecanismos psicológicos que podem induzir a manutenção da variação cultural entre grupos humanos distintos: a punição moral e o viés conformista.

Um dos mecanismos propostos pelos sociobiólogos para explicar a cooperação entre os animais é o altruísmo recíproco. Esse mecanismo baseia-se, por um lado, na manutenção da cooperação com os indivíduos que cooperaram no passado ou que têm uma boa reputação em um determinado grupo e, por outro, na punição dos oportunistas, que auferem os benefícios da cooperação sem pagar pelos seus custos.

Como discutido na primeira seção, a deserção é insuficiente para sustentar a cooperação em larga escala em razão da redução marginal dos custos da deserção. Mas esse problema é contornado quando a punição é aplicada pela própria comunidade (punição moral), e não por um único indivíduo. No modelo proposto pelo altruísmo recíproco, a severidade da sanção aplicada por um indivíduo altruísta ao oportunista diminui à medida que o grupo cresce porque há cada vez mais indivíduos a serem explorados (diminuição marginal do custo da retaliação). A punição moral aumenta os custos do oportunismo porque é aplicada por toda a comunidade, e não apenas por um único indivíduo (Boyd \& Richerson 2005, p. 200). Segundo Richerson e Boyd, esse modelo consegue explicar como o comportamento cooperativo poderia ser mantido em grupos maiores do que os que seriam sustentados pelo altruísmo recíproco e mesmo pela punição moral dirigida apenas aos oportunistas de primeiro nível. Mas o mecanismo tem um efeito colateral: ele pode sustentar não apenas comportamentos altruístas, mas também qualquer outro tipo de comportamento!

As evidências das ciências sociais também caminham nesse sentido: as sociedades reforçam suas convenções sociais aplicando sanções àqueles que não as cumprem, por mais frívolas e inúteis que pareçam. Assim, uma imensa quantidade de 
comportamentos pode ser estabilizada em uma sociedade por meio da punição moral - entre eles, a cooperação (Boyd et al. 2005, p. 201).

Os fundamentos psicológicos da punição moral não são especificamente humanos. Há evidência de que outros primatas, como os chimpanzés, avaliam constantemente a reputação dos membros de seu grupo e punem os que não respeitam a hierarquia estabelecida enquanto não houver uma nova acomodação de forças (Boehm, 1999, pp. 23-30). Como os hominíneos compartilham um ancestral comum com os chimpanzés, é uma suposição plausível que a capacidade psicológica de monitorar e punir indivíduos oportunistas - e, portanto, de raciocinar reciprocamente - já estivesse presente na psicologia dos primeiros hominíneos (Boehm 1999, pp. 149-50).

A punição moral pode estabilizar a variação cultural porque eleva os custos de comportamentos distintos dos exibidos pelo restante do grupo, favorecendo que os indivíduos adotem as variantes culturais que prevalecem na comunidade. Um indivíduo que se comporte da maneira considerada 'errada' - isto é, em desarmonia com as variantes culturais adotadas pelo grupo - sofrerá as sanções e terá, portanto, uma aptidão inferior à dos que as adotam. Caso ele não adotasse as variantes culturais que caracterizam o grupo, dificilmente seria imitado pelos demais e, além disso, tenderia a ser menos atraente. Por essa razão, mesmo que o indivíduo não avalie positivamente/aceite as variantes culturais adotas pelo grupo, ele pode adotá-las apenas para evitar as sanções. O efeito da punição pode ser tão intenso que levaria os indivíduos a adotarem comportamentos contrários aos induzidos por suas predisposições psicológicas inatas (Richerson \& Boyd 2005, p. 204).

Assim, a punição moral pode estabilizar uma determinada variante cultural, impedindo que outras variantes se estabeleçam e possibilitando a variação cultural entre grupos distintos. Mesmo que os índices de migração sejam razoavelmente elevados, ainda assim a variação entre os grupos se manteria, pois os imigrantes teriam que se sujeitar às variantes culturais do grupo em que estão ingressando.

Outro mecanismo psicológico que favorece a manutenção da variação cultural entre grupos diferentes é o viés conformista. A seleção natural favoreceu, na linhagem hominínea, uma psicologia inata que predispõe a imitar as variantes culturais mais comuns em uma população, favorecendo a sua disseminação e a diminuição da frequência das mais raras (Richerson \& Boyd 2005, pp. 203-4). A instabilidade climática do Pleistoceno nos últimos dois milhões de anos favoreceu a evolução de animais capazes de imitar os outros e, concomitantemente, a evolução do viés conformista. A linhagem hominínea foi especialmente favorecida, pois já reunia as precondições psicológicas necessárias para a capacidade da imitação. Não há consenso a respeito de qual seria essa precondição psicológica, apesar de alguns autores (entre eles Richerson e Boyd) sugerirem que seja a leitura de mentes, isto é, a capacidade de atribuir estados mentais a outros indivíduos.

Segundo Cheney e Seyfarth (2007, p. 163-71), os primatas não humanos são 
incapazes de imitar efetivamente porque não desenvolveram de modo pleno a capacidade de ler mentes (mindreading). Alguns primatas, como os chimpanzés, seriam capazes de ler alguns dos estados mentais de outros indivíduos (como desejos e intenções, mas não crenças, por exemplo), mas ainda assim seria insuficiente para tornar possível a acumulação cultural. ${ }^{9}$ Isso sugere que a leitura de mentes é uma capacidade que admite diferentes graus de competência, sendo que um determinado grau seria necessário para possibilitar a acumulação de cultura.

Em determinado momento de nossa história evolutiva, algum dos ancestrais humanos reuniu as precondições psicológicas necessárias para que pudesse imitar. Provavelmente, isso ocorreu entre 350.000 anos e 200.000 anos atrás, período no qual surgiram as primeiras evidências de acumulação cultural (Mithen 1998). É difícil ter certeza a respeito de qual de nossos ancestrais foi a primeira espécie capaz de imitar, já que no período conviviam várias espécies hominíneas, como o Homo heidelbergensis (de aproximadamente 800.000 a 300.000 anos atrás), o Homo neanderthalensis (de 250.000 a cerca de 30.000 anos atrás) e o próprio Homo sapiens moderno, que surgiu há aproximadamente 200.000 anos (Fleagle 1998, pp. 535-7; Coolidge \& Wynn 2009, p. 247). ${ }^{10}$

Há cerca de 200.000 anos, portanto, a mente de nossos ancestrais já era dotada das precondições psicológicas (a imitação, o viés conformista e a disposição a punir moralmente, entre outras) necessárias para manter a diferenciação cultural entre os vários grupos humanos.

Com o surgimento de vários grupos de hominídeos, é provável que tenha sido satisfeita também a terceira condição para que a seleção natural opere no nível do grupo - a competição. Há evidências antropológicas que indicam isso. Um dos modos pelos quais os antropólogos inferem o comportamento das sociedades préhistóricas é pelo estudo das sociedades arcaicas contemporâneas, que vivem em condições supostamente similares às daquelas comunidades. As pesquisas do antropólogo Joseph Soltis a partir de registros etnográficos realizados na Nova Guiné, por exemplo, sugerem que o conflito entre grupos é bastante comum (Soltis et al. 1995, p. 477). Irons (2009) chegou à mesma conclusão ao estudar grupos culturais entre os Ianomâmis, na Venezuela. Essas pesquisas dão respaldo empírico, portanto, à hipótese de que havia competição entre os diversos grupos culturais pré-históricos.

Com isso, estão presentes todos os elementos para que a seleção natural atue sobre as próprias comunidades: há variação (cultural) entre grupos, herança cultural em cada grupo e competição (conflitos intergrupais). A seleção de grupo, como se verá a seguir, é um elemento importante para a evolução da cooperação segundo a teoria da dupla herança. 


\subsection{A cooperação humana e os marcadores simbólicos}

A seleção de grupo induziu a evolução de uma psicologia inata capaz de se identificar com marcadores simbólicos que caracterizam um grupo social. Segundo Richerson e Boyd, essa propensão é uma característica peculiar da psicologia humana, presente em praticamente todas as nossas atividades sociais: os torcedores de futebol se identificam com os símbolos de sua equipe; os cidadãos de um país se identificam com sua bandeira; membros de uma profissão são associados a determinadas vestimentas. Advogados, políticos e empresários usam terno; bombeiros e policiais, o uniforme que os caracteriza; os religiosos utilizam determinadas roupas que também são bastante peculiares e os identificam.

Segundo Richerson e Boyd, esse traço da psicologia humana decorreu da adaptação cultural rápida, por duas razões. Em primeiro lugar, a marcação simbólica possibilita que as pessoas identifiquem quem faz parte do seu grupo social. A imitação, então, passa

a ser seletiva, pois os indivíduos imitam preferencialmente/exclusivamente os membros de sua comunidade. Quando a adaptação cultural é rápida, a população local de um grupo é uma fonte valiosa de informação a respeito de qual comportamento é adaptativo. Copiar o que a maioria está fazendo em uma determinada região (comportamento favorecido pelo viés conformista) aumenta as chances de se adotar o comportamento correto.

Além da imitação seletiva, a capacidade de se identificar com marcadores simbólicos (e, portanto, a de identificar quem faz parte do mesmo grupo) possibilita a interação social seletiva: é melhor interagir com quem partilha das mesmas normas sociais, de forma a evitar punições e usufruir das recompensas da vida social. Uma vez que marcadores simbólicos confiáveis existam, a seleção favorecerá a propensão psicológica a imitar e a interagir com indivíduos que compartilham dos mesmos marcadores simbólicos, estabilizando a cooperação no interior de um grupo cultural (Richerson \& Boyd 2005, p. 212).

A marcação simbólica é um elemento bastante importante para compreender a evolução da cooperação humana. Para ser adaptativa, a marcação simbólica não pode se fundamentar em símbolos que identifiquem altruístas, mas sim que possibilitem formar uma identidade sólida com um determinado grupo:

Muitas pessoas pensam que os marcadores étnicos surgem porque possibilitam altruístas a reconhecer outros altruístas. O problema com essa ideia é que símbolos são falsificados facilmente. A conversa é barata, assim como tinta de cabelo. Alardear que você é um altruísta é perigoso porque é fácil para as pessoas más sinalizarem que são boas pessoas. Se você usa um grande A no seu peito, estará sujeito a atrair amigos falsos que asseguram os benefícios de seu bom coração, mas não dão nada em troca. De fato, sociopatas parecem ser razoavelmente bons em simular o comportamento

Principia 16(1): 1-32 (2012). 


\begin{abstract}
de boas pessoas, na busca de seus esquemas predatórios. O que pode evoluir são marcadores que sinalizem que você é membro de um grupo que compartilha normas cooperativas que são executadas pela punição moral. Assim, comportar-se altruistamente é de seu próprio interesse, e alardear que você é membro de uma comunidade moral não lhe expõe à exploração por sociopatas, porque os moralistas de sua comunidade punirão quem o explorar. Usar os sinais de uma comunidade cujo altruísmo é protegido por normas morais e pela punição moral suplementa a conversa barata com um grande porrete (Richerson \& Boyd 2005, p. 213).
\end{abstract}

Assim, os marcadores simbólicos sinalizam a pertença a uma comunidade moral que aplica as normas que fazem parte de sua cultura. $\mathrm{O}$ viés conformista facilita a aprendizagem dessas normas, que são imitadas e reforçadas pela comunidade por meio da punição.

É provável que alguns dos elementos necessários para a evolução da psicologia que sustenta a marcação simbólica estejam relacionados também à evolução da linguagem. Segundo Robin Dunbar, a linguagem é um elemento importantíssimo na sustentação da cooperação humana em grandes grupos. Ele argumenta que os primatas necessitaram sobreviver em grupos cada vez maiores, tanto para a defesa contra predadores quanto para a defesa de recursos ambientais e contra outros grupos da mesma espécie - o que reforçaria a tese da intensidade da seleção de grupo (Dunbar 2002, p. 118). Contudo, a estabilidade da vida em sociedades grandes compostas por indivíduos não aparentados depende do constante monitoramento. Cada indivíduo precisa monitorar o comportamento dos demais, com o objetivo de identificar quem merece sua confiança ou quem é seu inimigo. A tese defendida por Dunbar é a de que, com o crescimento dos grupos sociais, o tempo destinado ao monitoramento das atividades sociais tornou-se cada vez maior, com o aumento no número de indivíduos. Entre os primatas, um mecanismo bastante utilizado para realizar esse monitoramento é a catação (grooming), procedimento pelo qual um indivíduo cata parasitas e sujeiras de outro indivíduos, que permanece relaxado e exposto a um eventual agressor - e, por isso, somente é realizado entre indivíduos que têm laços próximos, possibilitando o seu monitoramento. Todavia, é um processo custoso, pois o tempo gasto com as interações sociais é subtraído ao tempo necessário para outras atividades cruciais para a sobrevivência, como a busca por alimentos ou por parceiros sexuais (Dunbar 2002, p. 78). Assim, o crescimento dos grupos de primatas depende da quantidade de tempo de interação social disponível: a partir de um certo limite, o tempo gasto com essas atividades passa a interferir nas outras atividades, tornando improvável a evolução de espécies que usem a catação por mais tempo. Segundo Robin Dunbar esse limite é próximo a 30\% do tempo total de atividade diária. Entre primatas não-humanos, o recorde é do babuíno gelada, que destina cerca de $20 \%$ de seu tempo à catação.

Principia 16(1): 1-32 (2012). 
Dunbar também encontrou uma correlação estatística entre a proporção do neocórtex em relação ao volume total do cérebro, de um lado, e o tamanho dos grupos sociais em uma espécie, de outro. Quanto maior o volume cerebral relativo, maior o tamanho do grupo social: afinal, um neocórtex maior é capaz de monitorar uma quantidade maior de interações sociais. Na maior parte dos mamíferos, o neocórtex ocupa cerca de $30 \%$ do volume total de seus cérebros, mas nos primatas essa relação varia entre 50\% nos prossímios e 80\%, no caso humano (Dunbar 2002, p. 62). E o aumento nessa proporção veio acompanhado de um crescimento do tamanho dos grupos sociais. Evidências relativas à evolução na linhagem hominínea reforça a tese de Dunbar já que o aumento proporcional do neocórtex nessa linhagem está correlacionado ao aumento do tamanho médio dos grupos sociais (Dunbar 2002, p. 113).

Mas o aumento do tamanho dos grupos veio acompanhado de um custo bastante alto, relativo ao tempo gasto com o monitoramento das relações sociais: o Homo erectus, por exemplo, provavelmente passava cerca de $30 \%$ do dia nesse processo de catação. Quanto mais tempo é destinado a isso, menos tempo sobra para a realização de outras atividades necessárias para a sobrevivência. Segundo Dunbar o tempo máximo que um primata poderia destinar à catação sem que sua sobrevivência fosse ameaçada poderia sustentar um tamanho máximo de comunidade próximo a 120 indivíduos (Dunbar 2002, pp. 111-2). Esse limite, contudo, foi ultrapassado pelos ancestrais humanos em algum momento entre 500.000 e 250.000 anos atrás, quando o tamanho médio das comunidades humanas foi de 150 indivíduos. Isso exigiria um tempo de catação superior a 40\%, o que seria insustentável (Dunbar 2002, p. 114).

Dunbar propõe que a superação desse limite só foi possível porque os hominíneos substituíram, gradativamente, a catação por um outro mecanismo: a linguagem. À medida em que os grupos cresceram, mais e mais os primatas passaram a utilizar sons para transmitir significados. O macaco da espécie Cercopithecus diana, por exemplo, utiliza sons particulares para alertar sobre predadores específicos, como águias ou leões (Cheney \& Seyfarth 2007, pp. 260-1). Primatas geneticamente mais próximos dos humanos, como os chimpanzés, também utilizam sons para transmitir informações sociais estratégicas (Crockford \& Boesch, 2005).

A linguagem é mais eficiente do que a catação para manter a estabilidade da cooperação em grandes grupos por várias razões. A primeira delas se deve ao fato de que a linguagem possibilita a comunicação entre muitas pessoas ao mesmo tempo. Um indivíduo pode praticar a catação com um único indivíduo de cada vez, mas pode falar com vários ao mesmo tempo, o que facilita o monitoramento das interações sociais compostas por um número maior de indivíduos. Em segundo lugar, a comunicação linguística possibilita observar o comportamento de outros indivíduos concomitantemente à realização de outras atividades, diminuindo o tempo destinado às interações sociais. Além disso, a linguagem possibilita a troca de informação não 
apenas entre os indivíduos envolvidos no processo, mas entre outros indivíduos. Nas palavras de Dunbar "(... ) estou sugerindo que a linguagem evoluiu para possibilitar que pudéssemos fofocar (to gossip)" (Dunbar 2002, p. 79).

A linguagem teria passado a ter essa função em algum momento entre 500.000 e 250.000 anos atrás, sugerindo o autor que as evidências apontam para a existência de linguagem simbólica há cerca de 400.000 anos. Por exemplo, os Neandertais já teriam tido linguagem (Dunbar 2002, p. 116). ${ }^{11}$ É exatamente desse período, aliás, que datam as primeiras evidências de acumulação cultural nos grupos hominíneos, o que sugere um processo de coevolução entre vários elementos, culturais e genéticos: (i) o tamanho dos grupos; (ii) o tamanho relativo do neocórtex cerebral; (iii) a variação cultural entre grupos (o que pressupõe a acumulação cultural); (iv) o surgimento de marcadores simbólicos; e (iv) o alto custo da catação, que gradativamente levou à evolução da linguagem.

O processo de evolução da linguagem está intrinsecamente ligado à evolução dos marcadores simbólicos. A marcação simbólica pode ter sido o produto da seleção natural atuando sobre comunidades inteiras de indivíduos, aliada à variação cultural entre as várias comunidades. Uma de suas funções é a de possibilitar a identificação dos membros de um grupo com sua comunidade, diferenciando-a de outras comunidades. A dinâmica da evolução linguística sugere que a diferenciação entre línguas é um dos marcadores simbólicos mais poderosos para a manutenção da variação cultural entre comunidades. Comunidades que se separaram umas das outras ao longo do tempo passaram a falar dialetos ligeiramente diferentes, o que possibilitou diferenciar facilmente quem era membro do grupo e quem era estrangeiro (Dunbar 2002, p. 168; Cavalli-Sforza 1997).

Verifica-se, assim, a quantidade de elementos da vida social humana que podem ser explicados por meio da seleção de grupo, passando pelo tamanho das comunidades humanas, pela evolução da linguagem e pela moralidade, que é o objeto central deste artigo. Segundo Richerson e Boyd, todos esses aspectos presentes na evolução humana - a evolução cultural, a seleção de grupo e os marcadores simbólicos favoreceram a seleção de instintos específicos, que moldaram a forma da sociabilidade humana e mesmo a estrutura social de nossas comunidades. Essa é a hipótese dos instintos sociais tribais, o último dos elementos necessários para compreender a evolução de uma mente normativa.

\subsection{A hipótese dos instintos sociais tribais e a evolução de uma mente normativa}

Um dos resultados do processo coevolutivo entre genes e cultura foi a evolução de uma psicologia social bastante específica. A evolução cultural possibilitou o surgimento de grupos cooperativos imensos quando comparados às populações de outros

Principia 16(1): 1-32 (2012). 
primatas - um ambiente novo, caracterizado por uma imersão em nichos culturais e que favoreceu a evolução de instintos novos:

\begin{abstract}
A evolução cultural criou grupos cooperativos e simbolicamente marcados. Esse ambiente favoreceu a evolução de um conjunto de novos instintos ajustados à vida nesses grupos, incluindo uma psicologia que 'tem a expectativa' de que a vida seja estruturada por normas morais e que é projetada para aprender a internalizá-las; novas emoções, como vergonha e culpa, que aumentam a probabilidade de que essas normas sejam seguidas; e uma psicologia que espera a divisão do mundo social em marcadores simbólicos (Richerson \& Boyd 2005, p. 214).
\end{abstract}

A tese defendida é a de que, progressivamente, os ancestrais humanos se organizaram em grupos cada vez maiores, cujos membros eram bastante cooperativos internamente e se identificavam por meio de marcadores simbólicos. Os membros dessas comunidades eram altruístas com outros membros do grupo, mas agressivos com relação aos membros de outras comunidades o que levava, frequentemente, a conflitos intergrupais e ao surgimento de grupos cada vez maiores e culturalmente mais sofisticados.

Grupos equipados com variações culturais que tornassem mais provável a vitória contra outros grupos - como armas ou instituições que assegurassem a cooperação interna e punissem quem violava as normas sociais - , seriam capazes de vencer conflitos com grupos menores e portadores de variantes culturais menos favoráveis. Uma corrida armamentista (arms race) favoreceu a evolução social de comunidades cada vez maiores e mais cooperativas, internamente. Sociedades cujas instituições, valores e tecnologia conferissem vantagem no confronto com outras sociedades poderiam ser imitadas por outras, que poderiam ser estimuladas a inovar, inventando novas tecnologias e instituições, ou adotando valores que estimulassem a eficiência. Poderia ocorrer, então, o encadeamento evolutivo entre a tecnologia, as instituições e os valores de sociedades que disputassem entre si os mesmos recursos. Ao observar e imitar seletivamente a tecnologia, as instituições e os valores de seu inimigo, uma sociedade poderia implementar inovações sobre as variantes culturais copiadas e, assim, aumentar a sua eficiência no confronto. Essas inovações, por sua vez, também poderiam ser copiadas e melhoradas pelos seus inimigos, em um movimento coevolutivo.

As evidências arqueológicas citadas por Richerson \& Boyd sugerem que há cerca de 100.000 anos, no Pleistoceno, a estrutura das sociedades humanas era parecida com a das tribos contemporâneas de caçadores-coletores, como os !Kung San, que vivem no deserto do Kalahari, na Namíbia (Richerson \& Boyd 2005, p. 214).

Mas a estabilidade de grupos maiores só se tornou possível graças à evolução de novos instintos sociais (viés conformista, viés de seguir modelos, bem como instintos

Principia 16(1): 1-32 (2012). 
sociais como a vergonha, a empatia, e a propensão a punir moralmente), que resultaram dos mecanismos evolutivos descritos nas seções anteriores. A tese de Richerson e Boyd é resumida no seguinte trecho:

Suponha, como temos sugerido, que a evolução cultural levou a um ambiente social em que não-cooperadores estão sujeitos à punição pelos outros. Em muitas circunstâncias, a recompensa pela não-cooperação pode ser usufruída logo, enquanto o custo da punição será sofrido mais tarde; as pessoas, portanto, que supervalorizam resultados imediatos se recusam a cooperar, mesmo que seja de seu próprio interesse fazê-lo. Se geralmente o comportamento cooperativo é favorecido na maioria dos ambientes sociais, a seleção pode favorecer instintos sociais geneticamente transmitidos que predispõem as pessoas a cooperar e a se identificar com grupos sociais maiores. Por exemplo, a seleção pode favorecer sentimentos como a culpa que tornam o oportunismo (defection) intrinsicamente custoso, porque traria os custos do oportunismo para o presente, onde seria adequadamente comparado com o custo da cooperação (Richerson \& Boyd 2005, pp. 214-5).

Esta é a hipótese dos instintos sociais tribais: a vida em grandes sociedades ao longo de várias gerações favoreceu a evolução genética de instintos e emoções que facilitam a sobrevivência em grupos culturais. Esses instintos, contudo, não eliminaram os instintos anteriores, que sustentavam a cooperação em outras espécies. A seleção natural não remodela todos os elementos biológicos de um organismo: pelo contrário, como ela atua a partir de pequenas mudanças, selecionando as que o tornam mais (ou menos) adaptado ao ambiente, normalmente as estruturas orgânicas preexistentes são apenas remodeladas e exaptadas para novas finalidades, ou agregadas a novas estruturas.

Assim, provavelmente muitos dos sistemas cerebrais/mentais relacionados à cooperação humana também derivam dos sistemas que organizam a sociabilidade nos outros animais. Como visto na primeira seção, a maior parte da cooperação em animais não-humanos pode ser explicada pela seleção de parentesco e pelo altruísmo recíproco, que dependem de instintos e emoções básicos. A seleção de parentesco, por exemplo, favorece a seleção de instintos que predisponham o animal a agir em defesa de interesses de animais geneticamente relacionados. O cuidado parental, por exemplo, pode ser explicado a partir desse mecanismo. Por outro lado, o altruísmo recíproco pode favorecer a seleção de instintos, emoções e estruturas mentais que tornem o animal capaz de detectar, nas relações sociais, quem é digno de confiança. E esses instintos também estão presentes na mente humana: em todas as culturas, os pais cuidam de seus filhos e as pessoas têm um carinho especial por seus parentes e, além disso, também monitoramos nossas relações sociais.

Sobrepostos a essas camadas de estruturas mentais que nos predispõem a certos comportamentos estariam os instintos sociais tribais, que dão suporte à cooperação 
em comunidades maiores. Isso significa que há um conflito inerente à psicologia moral humana: os instintos sociais tribais, que favorecem a cooperação em grupos grandes, muitas vezes entram em conflito com outros instintos, que favorecem a cooperação com familiares ou com amigos (Richerson \& Boyd 2005, p. 215).

Segundo a proposta dos autores, a evolução dos instintos sociais tribais é análoga à evolução de uma gramática universal. Segundo a tese da gramática gerativa, defendida por Noam Chomsky, as crianças são dotadas de mecanismos psicológicos que tornam possível o aprendizado rápido e acurado da linguagem utilizada em seu meio social. Esses mecanismos funcionam a partir de princípios universais que limitam a faixa de interpretações possíveis que as crianças podem atribuir às sentenças que escutam. Mas esses princípios são suficientemente abstratos de modo a possibilitar o aprendizado de uma infinidade de linguagens: os princípios são universais, mas os parâmetros são fixados culturalmente e, portanto, são variáveis (Richerson \& Boyd 2005, p. 215; Chomsky 1997). Em outras palavras, temos um 'instinto da linguagem' que, embora opere a partir de determinados princípios universais, é flexível o suficiente para possibilitar a diversidade de línguas que podemos observar. Richerson e Boyd propõem que esse instinto da linguagem teria coevoluído com as línguas empregadas pelos vários grupos humanos do Pleistoceno e que um processo análogo de coevolução entre genes e cultura também deve ter ocorrido entre os instintos sociais tribais e as normas sociais transmitidas culturalmente (2005, p. 216).

Nesses termos, o panorama evolutivo descrito pelos autores sugere um longo processo de coevolução entre cultura (incluindo as intervenções construtivas no ambiente, como as instituições pré-históricas) e os instintos sociais tribais, que deviam estar consolidados em nossa espécie por volta de 100.000 anos atrás, quando o Homo sapiens já vivia em tribos de tamanho e estrutura aproximadamente iguais às das sociedades de caçadores-coletores contemporâneas.

Sober e Sloan Wilson (1998) vão além da proposta de Richerson e Boyd, sugerindo um panorama evolutivo que poderia explicar como instituições como o direito, a moral e a religião poderiam ter evoluído. Segundo eles, as normas sociais (e a estrutura de custos e benefícios subjacente a elas) são adaptações culturais reforçadas pela punição e que poderiam levar à evolução de uma mente dotada dos instintos sociais necessários para a vida em comunidades orientadas por prescrições morais, jurídicas e religiosas.

Uma psicologia propensa a se identificar com marcadores simbólicos - que possibilitam a interação seletiva com os membros da mesma comunidade -, bem como a respeitar normas sociais (variantes culturais específicas que ditam o comportamento esperado e as punições aplicáveis), são elementos necessários para a sustentação de sistemas cooperativos como os humanos. Essa rede simbólica de variantes culturais está na origem dos sistemas normativos humanos, como o direito, a religião e a moral. 
Os instintos sociais tribais seriam os seguintes: (i) altruísmo e empatia; (ii) tendência a praticar punição moralista e a buscar recompensas; (iv) uma tendência à igualdade; e (iii) instintos que favorecem a identificação com marcadores simbólicos. Esse seria também o núcleo daquilo que foi denominado de mente normativa: uma mente capaz de raciocinar a partir de normas sociais e de aplicá-las a situações concretas, como as que examinamos. Esse processo não é necessariamente consciente: ao aplicar uma norma social ou ao reconhecer a justiça ou a injustiça de uma situação, muitas vezes sabemos qual é a decisão correta, mas não como justificá-la; e uma explicação possível para isso, compatível com tudo o que se discutiu até aqui, sugere que essa decisão é muitas vezes instintiva. Nessa hipótese, nossa mente opera a partir de uma gramática moral universal, que estrutura nossa experiência moral e a forma pela qual formulamos juízos normativos.

Quais as evidências para a existência desses instintos? O primeiro instinto sugerido por Richerson e Boyd diz respeito ao altruísmo e à empatia. Se a teoria da dupla herança estiver correta, os seres humanos seriam altruístas não apenas com pessoas geneticamente relacionadas (por seleção de parentesco), ou com indivíduos cuja reputação acompanham e com os quais se relacionam a partir de mecanismos de punição ou recompensa (altruísmo recíproco), mas também com pessoas completamente desconhecidas. Para demonstrar esse ponto, os autores recorrem a experimentos realizados por Daniel Batson, que dão suporte empírico à tese de que há uma ligação intrínseca entre altruísmo e empatia, chamada de 'hipótese da empatia-altruísmo' (Richerson \& Boyd 2005, pp. 217-8; Batson 1987, pp. 65-114).

O segundo grupo de instintos sociais tribais diz respeito a uma inclinação para a prática da punição moralista e para a busca de recompensas. Alguns experimentos econômicos elaborados por Ernst Fehr sugeriram que as pessoas têm uma forte inclinação para punir quem viola regras (Fehr \& Gächter 2001). Nos experimentos, baseados na aplicação de estruturas lógicas da teoria dos jogos, Fehr demonstrou que, muitas vezes, as pessoas aceitam ter um certo prejuízo para punir agentes oportunistas, que buscam explorar os benefícios da cooperação sem dar seu quinhão de contribuição.

Evidências antropológicas também reforçam a conclusão de que nós, humanos, somos propensos a punir quem viola normas ou tenta obter benefícios injustificadamente. O antropólogo darwinista Christopher Boehm, por exemplo, reuniu várias evidências etnográficas que sugerem a existência de um viés psicológico para a punição de quem não se conforma às normas de sua comunidade. Segundo o antropólogo, é uma característica universal de sociedades contemporâneas de caçadorescoletores a existência de mecanismos de controle social cujo objetivo precípuo é assegurar o cumprimento das normas sociais e a punição de quem as transgride. Esses mecanismos podem ser sutis - como a fofoca (assim como sugeriu Dunbar), a crítica e a exposição do transgressor ao ridículo - , ou drásticos, como a condenação 
ao ostracismo ou mesmo o assassinato (Boehm 1999, pp. 72-80).

Boehm vai além da mera documentação desses mecanismos de controle social, contudo. Segundo ele, esses mecanismos são fruto de uma psicologia que nos distingue fundamentalmente dos outros primatas - uma psicologia que valoriza a igualdade. E segundo o autor, esses mecanismos de controle social, nas sociedades arcaicas, objetivavam justamente a proteção contra qualquer um que viesse a subverter a relação de igualdade entre os indivíduos de uma tribo (Boehm 1999, p. 69).

A hipótese formulada por Boehm parte do pressuposto de que nossos ancestrais tornaram-se igualitários em razão de fatores culturais - que, em contrapartida, favoreceram a seleção de uma psicologia igualitária. Mas isso não significa dizer que somos totalmente diferentes de outros primatas, que vivem em sociedades estritamente hierárquicas: Boehm sugere que nosso igualitarismo é baseado em uma psicologia hierárquica inversa. Ao invés de as hierarquias humanas serem fundamentadas em uma pirâmide - na qual o topo é menor do que a base e há uma cadeia de comando distribuída por toda a comunidade — , a psicologia igualitária seria baseada em uma pirâmide invertida, na qual é o líder quem deve obediência às normas comunitárias (e não o contrário, como seria em uma hierarquia tradicional). Segundo o antropólogo, essa predisposição seria compatível com uma evolução gradativa da psicologia de nossos ancestrais, uma vez que não pressupõe uma revolução cognitiva rumo ao igualitarismo, mas apenas uma inversão da predisposição para a hierarquia que já existia na linhagem dos primatas (Boehm 1999, pp. 173-4).

O igualitarismo teria, por sua vez, reforçado a seleção de grupo. Em primeiro lugar, ele diminuiria a variação cultural dentro dos grupos, pois indivíduos que não adotassem o comportamento prescrito pela comunidade moral seriam punidos como alguém que estivesse tentando usurpar o poder do grupo. Além disso, ao reforçar a identidade cultural de um grupo, o igualitarismo estimularia a diferenciação cultural entre comunidades distintas (Boehm 1997, p. 101). Embora Boehm nada afirme sobre a questão, é possível supor que a psicologia igualitária tenha coevoluído com o viés conformista e a punição moral, na medida em que depende, intrinsecamente, da punição daqueles que não se conformam ao comportamento típico adotado e esperado pela comunidade moral.

Outro aspecto relevante salientado por Boehm diz respeito aos níveis de seleção responsáveis pelo comportamento igualitário. Embora enfatize o igualitarismo como um mecanismo propulsor da seleção de grupo, Boehm destaca que o comportamento igualitário é, na verdade, o produto da seleção natural atuando em vários níveis (Boehm 1999, p. 15). De certa maneira, seria possível dizer que uma psicologia igualitária é um equilíbrio entre as exigências da seleção de grupo e as da seleção individual. No nível do grupo, o igualitarismo possibilita o reforço das normas morais e dos elementos culturais que mantêm a comunidade diferenciada das demais e coesa internamente; mas, no nível individual, o igualitarismo representa 
uma garantia contra a usurpação do poder por parte de outros indivíduos. ${ }^{12}$

A formação de comunidades morais está intimamente relacionada ao último dos instintos sociais tribais destacados por Richerson e Boyd que resultaram dos processos evolutivos descritos ao longo do artigo - emoções ligadas aos marcadores simbólicos. Uma comunidade moral é caracterizada pelo compartilhamento de marcadores comuns que tornam um indivíduo ligado emocionalmente ao grupo. O psicólogo Henri Tajfel elaborou um experimento no qual demonstrou que as pessoas tendem a confiar mais naqueles que compartilham o mesmo marcador simbólico, por mais arbitrário que seja. Em um experimento típico, descrito por Richerson e Boyd, ele disse aos participantes que seriam submetidos a um teste de julgamento estético. Tajfel mostrou-lhes pinturas de Paul Klee e Wassily Kandinsky e pediu que indicassem as obras de que mais gostavam. Depois, dividiu os participantes arbitrariamente em dois grupos, insinuando que a divisão havia sido efetuada com base nas preferências apresentadas. Por fim, pediu aos participantes que dividissem uma determinada quantia de dinheiro com os membros de algum dos grupos. Embora não tivessem tido nenhum contato prévio com os outros participantes, a maior parte do dinheiro foi dividido com os membros do próprio grupo. Esses resultados sugerem, segundo Richerson e Boyd, uma tendência psicológica a confiar naqueles que compartilham dos mesmos marcadores simbólicos em situações de incerteza, resultado que confirma as previsões da teoria da dupla herança (2005, p. 222).

O antropólogo Francisco Gil-White também apresentou evidências sobre como nossa psicologia funciona ao classificar marcadores simbólicos. Segundo ele, os humanos usam, ao avaliar símbolos culturais, uma perspectiva essencialista semelhante à estratégia cognitiva utilizada para classificar espécies de animais e plantas. Ao classificar os membros de uma mesma espécie, as pessoas atribuem propriedades comuns (essências) que são transmitidas de pai para filho (Gil-White 2001, p. 515). Um dos experimentos foi realizado entre cazaques e mongóis: Gil-White solicitou aos membros de ambas as etnias que respondessem a perguntas realizadas com o objetivo de verificar se eles reconheciam elementos essenciais que distinguissem mongóis e cazaques. As respostas dadas pelos participantes demonstram uma tendência ao raciocínio essencialista, em que determinadas qualidades eram atribuídas aos indivíduos pelo simples fato de apresentarem um ou outro marcador simbólico. Segundo Gil-White, isso ocorre porque temos a predisposição psicológica de pensar segundo tipos naturais (natural kinds): as pessoas classificam umas às outras de acordo com propriedades essenciais, dividindo-as conforme os marcadores simbólicos relevantes (no caso, a etnia). E as características salientes dos portadores dos marcadores simbólicos indicam em quem se pode confiar e quem não é digno de confiança.

A teoria de Richerson e Boyd, contudo, vai além da mera descrição e apresentação de evidências empíricas a respeito dos instintos sociais tribais. Segundo os autores, as sociedades contemporâneas são baseadas nesses instintos. ${ }^{13}$ Uma ques- 
tão que surge, nesse contexto, é a seguinte: segundo a hipótese dos instintos sociais tribais, a psicologia humana seria igualitária. Mas as sociedades contemporâneas, assim como boa parte das sociedades ao longo da história, são hierárquicas e desiguais. Como explicar essa incongruência?

Segundo a hipótese proposta pelos autores, a hierarquização e a desigualdade são o resultado da evolução cultural. As sociedades cresceram enormemente ao longo dos últimos 10.000 anos (no período conhecido como Holoceno), tanto em razão da estabilização climática que possibilitou o advento da agricultura (Richerson et al. 2001), quanto em decorrência da competição entre os grupos humanos, que favoreceu sociedades mais complexas e organizadas em detrimento de sociedades que se mantiveram organizadas à luz dos princípios de organização tribais. Sociedades hierarquizadas e segmentadas prevaleceram porque podem efetuar uma melhor divisão do trabalho, assegurando maior produtividade econômica e uma especialização militar que as torna mais aptas a vencer conflitos armados com outras sociedades (Luhmann 1983, pp. 204-205).

Mas como essas sociedades puderam vir a existir, se a sua base de organização está em conflito, supostamente, com nossa psicologia inata? Segundo a hipótese dos instintos sociais tribais, as sociedades complexas são possíveis porque são, ao mesmo tempo, hierarquizadas e compatíveis com nossa psicologia. O equilíbrio entre as exigências da hierarquização e as dos instintos sociais tribais só é possível porque as instituições sociais são moldadas à luz daqueles instintos, embora, em seu conjunto, possam sustentar uma vida social cada vez mais complexa. Em outras palavras, as instituições são divididas em grupos menores, no interior dos quais está replicado um ambiente próximo ao esperado por nossa psicologia inata: grupos compostos por um número máximo de 150 indivíduos, internamente igualitários e organizados em torno de valores comuns. Em outras palavras, as instituições são segmentadas em níveis subordinados uns aos outros, mas, internamente, são organizados como pequenas tribos (Richerson \& Boyd 1999, p. 276).

Além disso, as sociedades humanas são fundamentadas em normas sociais baseadas na lealdade aos que adotam os mesmos marcadores simbólicos. Ao contrário do que um hobbesiano poderia dizer, as normas sociais não se sustentam unicamente na força, mas em um sistema intrincado que combina a aplicação de sanções (punição moral) com um senso de solidariedade orgânica que lhe dá a legitimidade necessária para que o grupo entenda como necessário o sistema de sanções.

\section{Conclusão}

Compreender os fundamentos psicológicos da moralidade é uma tarefa que depende de uma abordagem cognitiva do raciocínio normativo, como têm demonstrado as recentes pesquisas nos mais diferentes domínios - biologia evolutiva, neuroeconomia, 
psicologia cognitiva, antropologia darwinista, ecologia humana, economia comportamental, entre outros. Todas essas abordagens partem da premissa de que entender a estrutura da cognição humana é fundamental para elaborar uma teoria moralidade em bases naturalistas.

O propósito do presente artigo foi apresentar o potencial de uma teoria de coevolução gene-cultura para explicar a cognição moral humana, sem desconsiderar a relevância das abordagens mencionadas no parágrafo anterior. Ao adotar a premissa de que a mente humana evoluiu como produto de dois sistemas evolutivos - um deles com base em herança genética e o outro em herança cultural - a teoria da dupla herança apresenta uma perspectiva capaz de conciliar a biologia e as ciências sociais, que estiveram nas últimas décadas do século $\mathrm{XX}$ receosas de abordagens naturalistas do comportamento humano.

Ao reconstruir a trajetória humana considerando processos de coevolução entre genes e cultura, é possível discutir numa perspectiva naturalista temas que normalmente são tratados sem se levar em consideração o conhecimento científico relevante produzido em diferentes áreas do saber. A interdisciplinaridade na compreensão da evolução humana possibilita o diálogo produtivo entre as ciências e a filosofia, tornando possível investigar, com maior profundidade, fenômenos - como a moral que antes não eram investigados a partir de uma abordagem naturalista.

\section{Referências}

Abrantes, P. C. C. \& Almeida, F. P. L. 2011. Evolução humana: a teoria da dupla herança. In: P. C. C. Abrantes (org.) Filosofia da biologia. Porto Alegre: Artmed, pp. 261-95.

Baston, D. C. 1987. Prosocial motivation: is it ever truly altruistic? In: L. Berkowitz Advances in experimental social psychology. Vol. 20. San Diego (CA): Academic Press, pp. 65-122.

Boehm, C. 1999. Hierarchy in the forest: the evolution of egalitarian behavior. Cambridge (MA): Harvard University Press,

- Impact of the human egalitarian syndrome on darwinian selection mechanics. The american naturalist 150 (Julho de 1997): 100-21.

Boyd, R.; Henrich, J.; Richerson, P. J. 2005. Weak conformist transmission can stabilize costly enforcement of norms in cooperative dilemmas. In: R. Boyd and P. J. Richerson. The origin and evolution of cultures. New York: Oxford University Press, pp. 189-203.

Boyd, R. \& Richerson, P. J. 2005. Simple models of complex phenomena: the case of cultural evolution. In: R. Boyd and P. J. Richerson. The origin and evolution of cultures. New York: Oxford University Press, pp. 397-419.

Cavalli-Sforza, L. L. 1997. Genes, peoples, and languages. Proceedings of The National Academy of Sciences of the USA 94: 7719-24 (Julho de 1997).

Cheney, D. \& Seyfarth, R. 2007. Baboon Metaphysics: the evolution of a social mind. Chicago: The University of Chicago Press.

Chomsky, N. 1997. Novos horizontes no estudo da linguagem. Delta: documentação de estudos em linguística teórica e aplicada 13: 51-74.

Principia 16(1): 1-32 (2012). 
Coolidge, F. L. \& Wynn, T. 2009. The rise of the Homo sapiens: the evolution of modern thinking. Malden (MA): Blackwell Publishing.

Crockford, C. \& Boesch, C. 2005. Call combinations in wild chimpanzees. Behaviour 142,(4): 397-421.

Darwin, C. 2011. The descent of man. Kindle edition. Amazon Digital Services.

- 2004. The descent of man, and selection in relation to sex. (2. ed). Londres: Penguin.

Dawkins, R. 2001. O gene egoísta. Trad. Geraldo H. M. Florsheim. Belo Horizonte: Itatiaia.

Dean, L. G. et al. 2012. Identification of the social and cognitive processes underlying human cumulative culture. Science 335(6072): 1114-18.

De Waal, F. B. M. 2006. Joint ventures require joint payoffs: fairness among primates. Social research: an international quarterly 73(2): 349-64.

- 2009. The age of empathy: nature's lessons for a kinder society. New York: Harmony Books.

Dennett, D. 1998. A perigosa ideia de Darwin: a evolução e os significados da vida. Rio de Janeiro: Rocco.

- 2003. Freedom evolves. New York: Penguin Books.

Dunbar, R. 2002. Grooming, gossip, and the evolution of language. Cambridge (MA): Harvard University Press.

Fehr, E. \& Gächter, S. 2001. Altruistic punishment in humans. Nature(415): 137-40.

Fleagle, J. G. 1998. Primate adaptation and evolution. Academic Press.

Henrich, N. \& Henrich, J. 2007. Why humans cooperate: a cultural and evolutionary explanation. New York: Oxford University Pess.

Irons, W. 2009. Genes and cultures - Boyd and Richerson: the intertwined roles of genes and culture in human evolution. Zygon 4(2): 347-54.

Klein, R. \& Edgar, B. 2002. The dawn of human culture. New York: John Willey \& Sons.

Laland, K. N. \& Brown, G. 2002. Sense and nonsense: evolutionary perspectives on human behavior. New York: Oxford University Press.

Luhmann, N. 1983. Sociologia do Direito I. Trad. Gustavo Bayer. Rio de Janeiro: Edições Tempo Brasileiro.

Mithen, S. 1998. A pré-história da mente: uma busca das origens da arte, da religião e da ciência. Trad. Laura Cardellini Barbosa de Oliveira. São Paulo: Unesp.

Okasha, S. 2006. Evolution and the levels of selection. Kindle edition. New York: Oxford University Press.

Richerson, P. J. \& Boyd, R. T. 2005. Not by genes alone: how culture transformed human evolution. Chicago: The University of Chicago Press.

. 1999. Complex societies: the evolutionary origins of a crude superorganism. Human Nature 10: 253-89.

Ruse, M. 1983. Sociobiologia: senso ou contra-senso? Trad. Cláudia Regis Junqueira. Belo Horizonte: Itatiaia.

Richerson, P. J.; Boyd, R. T.; Henrich, J. 2002. Cultural evolution of human cooperation. In: P. Hammerstein (org.) Genetic and cultural evolution of cooperation. Cambridge (MA): The MIT Press, pp. 357-88.

Sober, E. \& Wilson, D. S. 1998. Unto others: the evolution and psychology of unselfish behavior. Cambridge (MA): Harvard University Press.

Principia 16(1): 1-32 (2012). 
Soltis, J.; Boyd, R. T.; Richerson, P. 1995. Can group-functional behaviors evolve by cultural group selection? Current Anthropology 36(3): 473-94.

Szathmáry, E. \& Wolper, L. 2002. The transition from single cells to multicellularity. In: P. Hammerstein (org.) Genetic and cultural evolution of cooperation. Cambridge (MA): The MIT Press, pp. 271-90.

Trivers, R. 1971. The evolution of reciprocal altruism. The quarterly review of biology 46(1): 35-57.

Wilson, E. O. 1994. Naturalist. Washington (DC): Island Press.

Wright, R. 1994. The moral animal - why we are the way we are: the new science of evolutionary psychology. New York: Vintage Books.

Fábio Portela Lopes de Almeida Faculdade de Direito Universidade de Brasília Brasília, DF

fabio.portela@gmail.com

Paulo Cesar Coelho Abrantes Departamento de Filosofia Universidade de Brasília Brasília, DF abrantes@unb.br

Resumo. A teoria darwinista tem contribuído para a discussão de problemas nos mais diversos campos filosóficos, entre os quais se inclui a ética e a teoria moral. A sociobiologia e a psicologia evolucionista elucidaram muitos aspectos do comportamento social de diversas espécies animais, a partir de mecanismos como a seleção de parentesco e o altruísmo recíproco que, contudo, são insuficientes para explicar a cooperação no caso humano. Como alternativa, a teoria da dupla herança busca explicar o comportamento humano considerando tanto a biologia quanto as ciências sociais. Segundo esta abordagem, a psicologia social humana é caracterizada por instintos sociais tribais e marcadores simbólicos, que resultam em uma mente que pressupõe princípios morais inatos e universais, selecionados para a vida em grupos orientados por normas sociais, mas que são plasticamente moldados à realidade cultural de cada sociedade.

Palavras-chave: Dupla herança; evolução da moralidade; ética; darwinismo

\section{Notas}

${ }^{1}$ Os termos 'altruísmo' e 'cooperação' serão utilizados como sinônimos. Esses termos têm o mesmo significado, mas raízes distintas. Como explicam Elliott Sober e David Sloan Wilson, o termo cooperação é bastante utilizado na teoria dos jogos, ao passo que os biólogos evolutivos dão preferência ao termo altruísmo (Sober \& Wilson 1998, p. 84).

${ }^{2}$ Não há consenso a respeito da tradução adequada para o termo 'free-rider', que é muito utilizado pela literatura anglo-saxã em teoria dos jogos, e que também foi incorporada por muitos autores ao tratar deste problema. Nesse contexto, outro termo muito utilizado é 'desertion'. Em Abrantes \& Almeida (2011), optou-se pelo termo 'desertor', mas no presente texto preferiu-se utilizar, como sinônimos, as expressões 'aproveitador' e 'oportunista'.

Principia 16(1): 1-32 (2012). 
${ }^{3}$ É importante destacar que o conceito de altruísmo que se debate no âmbito biológico é distinto do conceito debatido na filosofia moral. Por isso, antes de prosseguir, é importante distinguir duas categorias diferentes de altruísmo: o altruísmo em um sentido psicológico e o altruísmo em um sentido evolutivo. Em regras gerais, o altruísmo psicológico se refere a estados psicológicos que levam um indivíduo a se preocupar, genuinamente, com o bemestar de outros como um fim em si mesmo (Sober \& Wilson 1998, p. 228). É a essa definição de altruísmo que, normalmente, um filósofo moral se refere. O altruísmo em sentido evolutivo, por sua vez, alude aos mecanismos presentes na história evolutiva de uma determinada espécie e que tornam possível explicar porque o comportamento altruísta evoluiu (Sober \& Wilson 1998, p. 199). O altruísmo psicológico remete à causa próxima do comportamento altruísta; o altruísmo evolutivo remete à causa última (remota) daquele mesmo comportamento - em outras palavras, os mecanismos psicológicos que levam alguém a ser um altruísta genuíno são fruto de uma longa história evolutiva.

${ }^{4}$ É importante estabelecer uma distinção entre aquilo que Ernst Mayr chamou de causas próximas e causas últimas em biologia (Boyd et al. 2005, p. 256). Causas próximas são os mecanismos fisiológicos e psicológicos que causam imediatamente um determinado comportamento animal. As causas últimas (ou remotas), por sua vez, dizem respeito às causas que levaram à evolução daquele traço biológico.

${ }^{5}$ Essa perspectiva guarda semelhança com a memética, abordagem sugeridada primeiramente por Richard Dawkins no livro "O gene egoísta". Segundo a memética, a cultura é um conjunto de variantes culturais discretas (que ele denominou de 'memes'), e que são replicadas com precisão por processos sociais de aprendizado (como a imitação e o ensino). Segundo a tese de Dawkins, os memes seriam as menores partículas de informação cultural com sentido que podem ser replicadas. Apesar da semelhança entre as variantes culturais e os memes, Richerson e Boyd rejeitam a proposta da memética. Segundo eles, as variantes culturais não precisam ser discretas ou mesmo replicáveis. Além disso, a analogia entre genes e variantes culturais não é completa, uma vez que forças evolutivas diferentes atuam na evolução cultural e biológica, como se verá adiante (Richerson \& Boyd 2005, pp. 6-7).

${ }^{6}$ A expressão 'evolução da cultura' pode trazer embutidos pelo menos dois sentidos bastante diferentes. O primeiro deles se relaciona à evolução da própria cultura como sistema de herança: diz respeito à sua função biológica e ao modo pelo qual ela surgiu e se tornou tão importante na linhagem hominínea. O segundo sentido da expressão remete à ideia de que a própria cultura evolui ao longo do tempo.

${ }^{7}$ É importante ressaltar a existência de desanalogias (analogias negativas) entre a evolução genética e a evolução cultural. A evolução cultural, por exemplo, tem elementos lamarckistas, pois diz respeito à herança de caracteres adquiridos, tese profundamente rejeitada no âmbito da evolução com base genética. Cf., a propósito, Abrantes \& Almeida 2011, p. 271. ${ }^{8}$ É importante lembrar da tese de Elliott Sober e Wilson (1998), para os quais seria possível redescrever os processos evolutivos mencionados pelos sociobiólogos a partir da perspectiva da seleção de grupo.

${ }^{9}$ A evidência de que outros primatas seriam capazes de imitar é escassa. Um dos exemplos mais citados na literatura - os macacos japoneses que lavam batatas antes de comê-las não é convincente. No estudo original de Nishida, menos da metade do grupo de 25 indivíduos adquiriu o hábito e, mesmo assim, apenas após um período de três anos, o que sugere que o comportamento foi aprendido individualmente, e não por imitação (Cheney 
\& Seyfarth 2007, p. 186). Além disso, pesquisa recente de Dean et al. (2012) demonstrou que apenas os humanos possuem as capazes cognitivas necessárias para a acumulação cultural. Os pesquisadores realizaram experimentos com chimpanzés, macacos capuchinhos e crianças nos quais as tarefas propostas somente poderiam ser realizadas com sucesso caso houvesse acumulação cultural, em razão das dificuldades de ordem cognitivas colocadas. Nas palavras dos autores: "Nossas descobertas, baseadas na confirmação de padrões previstos de covariância tanto entre espécies quanto dentro de uma mesma espécie, constituem um forte suporte para a tese de que a acumulação cultural requer um conjunto de processos psicológicos essenciais - especificamente, o ensino por meio de instrução verbal, imitação e tendências pró-sociais - que estão presentes em humanos, mas ausentes ou empobrecidas em chimpanzés e macacos capuchinhos" (Dean et al. 2012, p. 1117).

${ }^{10}$ Não há dúvidas de que Darwin era um gradualista, e que a atitude padrão da teoria darwinista é o gradualismo. Todavia, é possível - sem violar a premissa darwinista - sustentar que determinados caminhos evolutivos possam levar à evolução de um traço apenas em determinada espécie, que reunia pré-adaptações e vivia em condições ambientais muito específicas que favoreciam à evolução dele.

${ }^{11}$ É importante registrar, contudo, que essa hipótese não é consensual: Richard Klein e Blake Edgar, por exemplo, sugerem que a linguagem é o produto de uma mutação genética sofrida há 50.000 anos já entre os Homo sapiens (Klein \& Edgar 2002).

12 É importante ressaltar que o igualitarismo proposto por Boehm não é incompatível com a estruturação de sociedades hierárquicas, tão comuns na história humana. A tese do antropólogo darwinista supõe que a psicologia humana é adaptada a um ambiente social em que havia sociedades pequenas, compostas por um número muito pequeno de indivíduos. Se a tese de Dunbar (2002) estiver correta, essas sociedades tinham em torno de 150 membros, que viviam em uma estrutura social relativamente simples e igualitária - como tem reconhecido a antropologia, no que diz respeito às sociedades arcaicas. Com o crescimento das sociedades e a necessidade de uma organização social mais eficiente, tornou-se necessário o estabelecimento de hierarquias segmentadas (Luhmann 1983, p. 204-5). O equilíbrio entre as exigências da hierarquização e o igualitarismo só é possível porque as instituições sociais são organizadas de maneira compatível com ela - são divididas em grupos menores, no interior dos quais está replicado um ambiente próximo ao esperado por nossa psicologia inata: grupos compostos por um número aproximado de 150 indivíduos. Esses grupos são internamente igualitários e organizados em torno de valores comuns, que se relacionam hierarquicamente com outros grupos. Em outras palavras, as instituições são segmentadas em níveis que, estruturalmente, são subordinados uns aos outros, mas, internamente, são organizados como pequenas tribos (Richerson \& Boyd 1999, p. 276).

13 É importante salientar que o próprio Darwin, em "A descendência do homem", já destacava o papel dos instintos na manutenção da ordem social. Segundo Darwin, as faculdades sociais e morais necessárias para a vida social tribal (simpatia, fidelidade e coragem são destacadas por ele) foram adquiridas por meio da seleção natural. Darwin ainda prevê que tais qualidades seriam selecionadas no contexto de competição tribal entre os ancestrais humanos; as tribos mais coesas, cujos membros fossem mais corajosos e fiéis ao grupo, teriam vantagens em relação às demais e, portanto, tais qualidades seriam selecionadas (Darwin 2011, p. 2456)

Principia 16(1): 1-32 (2012). 